\title{
Croton argyrophyllus Kunth and Croton heliotropiifolius Kunth: Phytochemical characterization and bioactive properties
}

\author{
Sara Samanta da Silva Brito ${ }^{\mathrm{a}}$, Franceli Silva ${ }^{\mathrm{a}, * *}$, Ricardo Malheiro ${ }^{\mathrm{b}}$, Paula Baptista ${ }^{\mathrm{b}}$, \\ José Alberto Pereira ${ }^{\mathrm{b}, *}$ \\ ${ }^{\text {a }}$ Center for Agricultural, Environmental and Biological Sciences, Federal University of Recôncavo da Bahia (UFRB), University Campus, 44380-000, Cruz das Almas, \\ Bahia, Brazil \\ ${ }^{\mathbf{b}}$ Centro de Investigação de Montanha (CIMO), School of Agriculture, Polytechnic Institute of Bragança, Santa Apolónia Campus, 5300-253, Bragança, Portugal
}

\section{A R T I C L E I N F O}

\section{Keywords:}

Medicinal plants

Croton spp

Essential oil

Chemical composition

Bioactive properties

\begin{abstract}
A B S T R A C T
Croton heliotropiifolius Kunth and Croton argyrophyllus Kunth are endemic plant species from northeastern Brazil widely used in folk medicine and scarcely studied. In this context, the essential oils (EO's) and methanolic extracts (leaves and stalk) of both species were chemically characterized, and their antioxidant and antimicrobial activities were assessed. The chemical characterization of the EO's identified sixty components,being the major ones in C. argyrophyllus bicyclogermacrene (14.0\%), $\beta$-pinene (8.9\%) and spathulenol (8.7\%), and in C. heliotropiifolius limonene (16.9\%), $\alpha$-pinene (13.3\%) and caryophyllene (12.1\%). Essential oils and methanolic extracts from leaves of $C$. argyrophyllus possess greater antioxidant potential, which could be related to the high levels of total phenols and flavonols. The antimicrobial activity of $C$. argyrophyllus essential oil proven to be more efficient than chloramphenicol $\left(30 \mu \mathrm{g} \mathrm{mL}^{-1}\right)$, with a minimum inhibitory concentration (MIC) of $25 \mu \mathrm{L} \mathrm{mL}-1$ against Bacillus subtilis, Staphylococcus aureus, Escherichia coli and Pseudomonas aeruginosa and $10 \mu \mathrm{L} \mathrm{mL}{ }^{-1}$ against $B$. cereus. Leaf extracts presented high activity against yeasts ( $\mathrm{MIC}=50 \mathrm{mg} \mathrm{mL}^{-1}$ ) being $C$. heliotropiifolius effective against Candida albicans and C. parapsilosis, while C. argyrophyllus was effective against $C$. glabrata. Overall results showed that these plant species are potential sources of phytochemicals with interest in the fields of both pharmacology (e.g., antimicrobial) and human health (e.g., antioxidant). Furthermore, in the socio-economic aspect, these results can improve and disseminate the cultivation of these species, inducing improvements in the rural populations.
\end{abstract}

\section{Introduction}

The genus Croton, the most diverse genus of the Euphorbiaceae family, contains about 1300 species distributed across the world's tropical regions. In Brazil, around 350 of these species can be found, being 252 of them considered endemic (Secco et al., 2012). Croton great diversity in species is also reflected in their chemical constituents, most of them still unknown (Dória et al., 2010). Croton heliotropiifolius Kunth and Croton argyrophyllus Kunth are popularly known in Brazil as "velame" or "velame-branco" and "cassutinga". They are endemic species from northeastern Brazil and are frequently found in the vegetation of the Caatinga biome. These species are greatly used in folk medicine in Africa, Asia and South America, generally as stimulants, tranquilizers, insecticides, vermifuges and analgesics, among other uses (Compagnone et al., 2010).

Different chemical classes of compounds were identified in Croton species, such as terpenoids and phenylpropanoids, which could be related to the biological activity demonstrated by their species (Aguiar et al., 2016). Concerning to C. heliotropiifolius and C. argyrophyllus some important terpenic compounds, monoterpenes and sesquiterpenes, were identified namely limonene, $\beta$-caryophyllene, spathulenol, bicyclogermacrene and germacrene D (Fontenelle et al., 2008; Angélico et al., 2014; Souza et al., 2017).

Plant extracts and essential oils are good sources of molecules such as terpenoids, flavonoids, and tannins (Sun et al., 2015), that possess important biological activities. When present in food, due to their antimicrobial and antioxidant activities prevent the deterioration and increase the nutritional value. The importance of this type of matrices increases nowadays with the knowledge of the rise of resistance to human pathogenic bacteria and fungi to the available synthetic products (Grundmann et al., 2011). In this context, the use of plant extracts and essential oils in food and pharmaceutical industries has been

\footnotetext{
* Corresponding author at: Centro de Investigação de Montanha (CIMO), ESA, Instituto Politécnico de Bragança, Campus de Santa Apolónia, 5300-253, Bragança, Portugal.

** Corresponding author. Centre for Agricultural, Environmental and Biological Sciences, Federal University of Recôncavo da Bahia, 44380-000, Cruz das Almas, Bahia, Brazil.

E-mail addresses: franceli.silva@ufrb.edu.br (F. Silva), jpereira@ipb.pt (J.A. Pereira).
} 
growing significantly and is an open field with great potential. Recent works have demonstrated the antimicrobial, insecticidal and antioxidant activities of Croton species (Queiroz et al., 2014; Wijesundara et al., 2016) which are correlated with the chemical composition of their essential oils. Compounds present in the essential oils of some Croton species, such as spathulenol and caryophyllene oxide, have the capacity to inhibit the growth of some filamentous fungi species (Wenqiang et al., 2006); whereas bicyclogermacrene, $\alpha$-pinene and caryophyllene have been described to possess antimicrobial activity (Cavin et al., 2006; Morais et al., 2006; Ramos et al., 2013).

In this context, the main objective of this work is to contribute for the phytochemical characterization of two key plant species of established socio-economic importance in the Caatinga biome, namely $C$. heliotropiifolius and C. argyrophyllus. Exploitation of their essential oil and aerial part for bioactive compounds (i.e. antioxidant and antimicrobial) is imperative to better know the real potential of these plants as a source for drug development and use as a health supplement.

\section{Material and methods}

\subsection{Standards and reagents}

DPPH (2,2-diphenyl-1-picrylhydrazyl), ABTS [2,2-azino-bis(3ethylbenzothiazoline-6-sulfonic acid)], Trolox (6-hydroxy-2,5,7,8-tetramethylchroman-2-carboxylic acid), iron (III) chloride, potassium persulfate, trichloroacetic acid, gallic acid, quercetin, Tween 80 , rezasurin, dimethyl sulfoxide, sodium chloride, agar-agar and saturated alkanes series were obtained from Sigma-Aldrich (St. Louis, USA). Methanol (HPLC grade), ethanol absolute, sodium dihydrogen phosphate dihydrate, glucose, and potassium hexacyanoferrate (III) were purchased from Merck (Darmstadt, Germany). Hydrochloric acid, disodium hydrogen phosphate 2-hydrate, and caffeic acid were obtained from Panreac (Barcelona, Spain). Chloramphenicol and fluconazole were obtained from Oxoid Ltd (Basingstoke, UK). Yeast extract, peptone and tryptone were obtained from Himedia (Mumbai, India). The water was treated in a Milli-Q water purification system (Millipore, Bedford, MA, USA).

\subsection{Plant material}

Both species were collected in the Caatinga biome (Bahia, Brazil) between February and April 2016. Croton argyrophyllus was recovered in São Domingos (11 $\left.27^{\prime} 56^{\prime \prime S} 39^{\circ} 31^{\prime} 34^{\prime \prime W}\right)$, and C. heliotropiifolius in Conceição do Coité $\left(11^{\circ} 33^{\prime} 50^{\prime \prime}\right.$ S $39^{\circ} 16^{\prime} 58^{\prime \prime}$ W). Voucher species were deposited in the Herbarium of the Federal University of Recôncavo da Bahia, Cruz das Almas, with the catalog numbers HURB 15400, for $C$. heliotropiifolius, and HURB 15401 for C. argyrophyllus. For each species, six independent samples were taken and prepared separately.

\subsection{Distillation of essential oil and preparation of extracts}

The plant material was dried in a heated chamber with forced circulation at $40{ }^{\circ} \mathrm{C}$ until a constant weight was reached. This took around three to four days. After drying, the leaves were ground up manually and $50 \mathrm{~g}$ of them were placed in a balloon flask and distilled water was added up to a total volume of three liters. This mixture was then subjected to a hydrodistillation process in steam using Clevenger apparatus (model TE 2762 from Tecnal) for two hours, to obtain the essential oil.

Methanolic extracts were prepared from the leaves and stalk. Briefly, $500 \mathrm{~mL}$ of methanol (HPLC grade) was added to $50 \mathrm{~g}$ of plant material and the extraction was carried out during $72 \mathrm{~h}$, being the solvent renewed every $24 \mathrm{~h}(500 \mathrm{~mL}$ of methanol) and recovered through filtration. Once finished the $72 \mathrm{~h}$, the solvents were combined and the methanolic extract was obtained under vacuum in a rotary evaporator (RE300/MS, Bibby Scientific Limited, Staffordshire, UK) at a temperature of $40^{\circ} \mathrm{C}$. All the extractions, both for essential oils and methanolic extracts were carried out in triplicate.

\subsection{Characterization of essential oils}

The essential oils of $C$. argyrophyllus and C. heliotropiifolius were determined through gas chromatography analysis using mass spectrometry detection (GC/MS). Before injection, $10 \mu \mathrm{L}$ of the essential oil were diluted in $0.5 \mathrm{~mL}$ of methanol, and $1 \mu \mathrm{L}$ of the volume was injected.

\subsubsection{Gas chromatography with mass spectrometry detection (GC/MS)}

The gas chromatograph used was a Shimadzu model GC-2010 coupled to a GC/MS-QP 2010 Shimadzu mass spectrometer (Kyoto, Japan). A TRB-5MS capillary column $(30 \mathrm{~m} \times 0.25 \mathrm{~mm} \times 0.25 \mu \mathrm{m}$; Teknokroma, Spain) was used. The injector port (model AOC20i $+\mathrm{s}$ ) was heated to $220^{\circ} \mathrm{C}$, and the injections were performed in split mode (1:20). The oven temperature was programmed to start at $60^{\circ} \mathrm{C}$ and then increase by $3{ }^{\circ} \mathrm{C} / \mathrm{min}$ until reaching $240{ }^{\circ} \mathrm{C}$, and this was then maintained for $20 \mathrm{~min}$. The carrier gas was helium (Praxair, Portugal), at a linear velocity of $30 \mathrm{~cm} / \mathrm{s}$ and a total flow rate of $44.3 \mathrm{~mL} / \mathrm{min}$. The temperature of the ionization source was maintained at $240{ }^{\circ} \mathrm{C}$, the ionization energy at $70 \mathrm{eV}$, and the ionization current at $0.1 \mathrm{kV}$. Compounds were identified by comparing their MS spectra with those obtained from a database (NIST 11; the minimum identification similarity is $80 \%$ ), and with those of pure compounds analyzed under the same conditions, and by comparing the retention indices (in the form of Kovats indices, with the series of alkanes injected with the same chromatographic conditions used for the EO's) with data in the literature (Adams, 2007). Retention indices were calculated according to van Den Dool and Kratz (1963). The results were expressed as the relative percentages of each compound, calculated via normalization of the chromatographic peak areas.

\subsection{Antioxidant activity}

Three methodologies were used to evaluate the antioxidant potential of the species studied. For the essential oil, the 2,2-diphenyl-1-picrylhydrazyl (DPPH) and 2,2-azino-bis(3-ethylbenzothiazoline-6-sulfonic acid) (ABTS) methods were used, at concentrations ranging from 10 to $50 \mathrm{mg} \mathrm{mL}^{-1}$. For the methanolic extracts from the leaves and stalks, the DPPH, ABTS and reducing power methods were tested, at concentrations ranging from 0.1 to $2.0 \mathrm{mg} \mathrm{mL}^{-1}$. Trolox was used as a reference for the three methods at concentrations ranging from 0.0025 to $0.25 \mathrm{mg} \mathrm{mL}^{-1}$.

\subsubsection{Scavenging effect on $D P P H$ radicals}

The capacity to scavenge the DPPH free radical was monitored in accordance with the method of Hatano et al. (1988) with minor modifications. The extract solution/EO $(0.3 \mathrm{~mL})$ was mixed with $2.7 \mathrm{~mL}$ of a methanol solution containing DPPH radicals $\left(6 \times 10^{-5} \mathrm{~mol} \mathrm{~L}^{-1}\right)$. The mixture was shaken vigorously and left to stand for $60 \mathrm{~min}$ and three hours, respectively for the methanolic extracts and EO's, at room temperature in the dark (until stable absorbance values were obtained). The reduction of the DPPH radical was measured by continuous monitoring of the absorption decrease at $517 \mathrm{~nm}$ (Genesys 10UV, Thermo Electron Corporation). The DPPH scavenging effect was calculated as the percentage of DPPH discoloration, using the following formula: $\left[\left(A_{D P P H}-A_{S}\right) / A_{D P P H}\right] \times 100$, where $A_{S}$ was the absorbance of the solution when the sample extract has been added at a particular level, and $\mathrm{A}_{\mathrm{DPPH}}$ was the absorbance of the DPPH solution. The EO/methanolic extract concentration providing $50 \%$ inhibition $\left(\mathrm{EC}_{50}\right)$ was calculated from the graph of percentage scavenging effect against extract concentration in the solution.

\subsubsection{Scavenging effect on ABTS radicals}

The ABTS method was performed as described by Sánchez et al. 
(2007), based on the capacity of a sample to inhibit the ABTS radical. The ABTS scavenging effect was calculated as the percentage of ABTS discoloration, using the same formula as used for the DPPH method. The ABTS radical was generated by chemical reaction with potassium persulfate $\left(\mathrm{K}_{2} \mathrm{~S}_{2} \mathrm{O}_{8}\right)$. To $25 \mathrm{~mL}$ of ABTS $\left(7 \mathrm{mmol} \mathrm{L}^{-1}\right)$ were added $440 \mu \mathrm{L}$ of $\mathrm{K}_{2} \mathrm{~S}_{2} \mathrm{O}_{8}\left(140 \mathrm{mmol} \mathrm{L}^{-1}\right)$, being the solution kept in darkness during $12-16 \mathrm{~h}$ at room temperature in order to form the radical. An accurate volume of the previous solution was diluted in absolute ethanol until an absorbance of $0.70 \pm 0.02$ at $\lambda=734 \mathrm{~nm}$ (Genesys 10UV, Thermo Electron Corporation). Once the radical was formed $2 \mathrm{~mL}$ of the ABTS radical solution were mixed with $100 \mu \mathrm{L}$ of the methanolic extracts/EO and the absorbance measured at $\lambda=734 \mathrm{~nm}$. The ABTS scavenging effect and $\mathrm{EC}_{50}$ values were calculated according to the previously mentioned for the DPPH method.

\subsubsection{Reducing power}

The reducing power was determined in accordance with the procedure described by Berker et al. (2007). The extract solution ( $1 \mathrm{~mL}$ from 0.1 to $2 \mathrm{mg} \mathrm{mL}^{-1}$ ) was mixed with $2.5 \mathrm{~mL}$ of $200 \mathrm{mmol} \mathrm{L}^{-1}$ sodium phosphate buffer (pH 6.6) and $2.5 \mathrm{~mL}$ of $1 \%$ potassium ferricyanide. The mixture was incubated at $50{ }^{\circ} \mathrm{C}$ for $20 \mathrm{~min}$. After cooling, $2.5 \mathrm{~mL}$ of $10 \%$ trichloroacetic acid $(\mathrm{w} / \mathrm{v})$ were added and the mixture was centrifuged at $1000 \mathrm{rpm}$ for $8 \mathrm{~min}$ (Centorion K24OR-2003 refrigerated centrifuge). The upper layer $(2.5 \mathrm{~mL})$ was mixed with $2.5 \mathrm{~mL}$ of deionised water and $0.5 \mathrm{~mL}$ of $0.1 \%$ ferric chloride, and the absorbance was measured spectrophotometrically at $700 \mathrm{~nm}$ (higher absorbance readings indicate higher reducing power). Extract concentration providing 0.5 of absorbance $\left(\mathrm{EC}_{50}\right.$ ) was calculated from the graph of absorbance at $700 \mathrm{~nm}$ (Genesys 10UV, Thermo Electron Corporation) against extract concentration in the solution.

\subsection{Determination of different groups of phenolic compounds}

The total phenols, hydroxycinnamic acid derivatives and flavonols content were determined in triplicate in accordance with the methodology described by Boulanouar et al. (2013). One $\mathrm{mL}$ of the methanolic extract $\left(1 \mathrm{mg} \mathrm{mL}^{-1}\right)$ was diluted with $1 \mathrm{~mL}$ of aqueous ethanol ( $95 \% \mathrm{v} / \mathrm{v}$ ) containing $0.1 \%$ hydrochloric acid and $8 \mathrm{~mL}$ of $2 \%$ hydrochloric acid. The absorbance was measured at $280 \mathrm{~nm}$ to determine total phenols, $320 \mathrm{~nm}$ for hydroxycinnamic acid derivatives, and $360 \mathrm{~nm}$ for flavonols content (Genesys 10UV, Thermo Electron Corporation). The results were expressed as gallic acid equivalents (GAE) $\mathrm{g}^{-1}$ of extract for total phenols, caffeic acid equivalents (CAE) $\mathrm{g}^{-1}$ of extract for hydroxycinnamic acid derivatives and quercetin (QE) $g^{-1}$ of extract for flavonols. The calibration curves followed the same methodology applied to the methanolic extracts, with concentrations varying from 0.001 and $1 \mathrm{mM}$ for gallic and cafeic acids, and concentrations from 0.001 to $0.5 \mathrm{mM}$ for quercetin.

\subsection{Antimicrobial activity}

The antimicrobial activity of both the extracts and the essential oils obtained from C. argyrophyllus and C. heliotropiifolius were evaluated against Gram-positive bacteria (Bacillus cereus ATCC 7064, Bacillus subtilis 48886 and Staphylococcus aureus ATCC 6538), Gram-negative bacteria (Escherichia coli CECT 423 and Pseudomonas aeruginosa ATCC 10145), and yeasts (Candida albicans IGC 3436T, Candida glabrata IGC 2418T and Candida parapsilosis 28B), which were obtained from the collection from the University of Minho, Portugal. The yeast strains were maintained at $4{ }^{\circ} \mathrm{C}$ in YEPDA medium [(Yeast Extract-PeptoneDextrose-Agar) $1 \%(\mathrm{w} / \mathrm{v})$ yeast extract, $2 \%(\mathrm{w} / \mathrm{v})$ peptone, $2 \%(\mathrm{w} / \mathrm{v})$ glucose and $2 \%(\mathrm{w} / \mathrm{v})$ agar], and were subcultured periodically. Growth was promoted aerobically at $28^{\circ} \mathrm{C}$. Bacterial stock cultures were maintained at $4{ }^{\circ} \mathrm{C}$ in LBA medium [(Luria-Bertani Agar) tryptone $1 \%(\mathrm{w} / \mathrm{v})$, yeast extract $0.5 \%(\mathrm{w} / \mathrm{v}), \mathrm{NaCl} 1 \%(\mathrm{w} / \mathrm{v})$ and agar $2 \%(\mathrm{w} /$ v)], and were subcultured periodically at $37^{\circ} \mathrm{C}$.
The minimum inhibitory concentration (MIC) values for both the extracts and the essential oils were determined using a resazurin microtiter assay plate (Sarker et al., 2007) in YEPDA medium (for yeast) or LBA medium (for bacteria). Briefly, stock solutions of essential oils $\left(100 \mu \mathrm{LL}^{-1}\right.$ in $5 \%$ Tween 80$)$ and extracts $\left(100 \mathrm{mg} \mathrm{mL}^{-1}\right.$ in $10 \%$ dimethyl sulfoxide - DMSO) were diluted in broth medium, in 96-well microtiter plates, to yield final concentrations ranging from 10 to $50 \mu \mathrm{L} \mathrm{mL}^{-1}$ for essential oils and from 5 to $50 \mathrm{mg} \mathrm{mL}^{-1}$ for plant extracts. Each well was further inoculated with bacterium/yeast suspension to achieve the final concentration of $10^{6}$ colony-forming units $(\mathrm{CFU}) \mathrm{mL}^{-1}$, in a final volume of $150 \mu \mathrm{L}$. Chloramphenicol $\left(30 \mu \mathrm{g} \mathrm{mL}^{-1}\right)$ and fluconazole $\left(25 \mu \mathrm{g} \mathrm{mL}^{-1}\right)$ were used as positive controls for antibacterial and antifungal activity, respectively. Negative controls were carried out with resazurin and culture medium, and with the presence of the microorganisms, and no color changes were recorded, indicative that resazurin has no influence in the results obtained. Bacterium/yeast inoculum with $10 \%(\mathrm{v} / \mathrm{v})$ DMSO or $5 \%(\mathrm{v} / \mathrm{v})$ Tween 80 and without essential oils/extracts were also included as controls. All experiments were performed in triplicate. Antimicrobial activity was detected after $24 \mathrm{~h}$ of incubation at $25^{\circ} \mathrm{C}$ (for yeast) or $37^{\circ} \mathrm{C}$ (for bacteria), by adding $25 \mu \mathrm{L}$ (for bacteria) or $30 \mu \mathrm{L}$ (for yeast) of resazurin-staining aqueous solution $\left(0.15 \mathrm{mg} \mathrm{mL}^{-1}\right)$ to each well. Any color changes from purple to pink or colorless were recorded as positive for bacterial/yeast growth. MICs were recorded as the lowest concentration of extract/essential oil that inhibited the growth of bacteria/ yeast. The results were expressed as $\mathrm{mg} \mathrm{mL}^{-1}$ or $\mu \mathrm{LLL}^{-1}$ for methanolic extracts and essential oils, respectively.

\subsection{Statistical analysis}

Analysis of variance (ANOVA) was performed using the Sisvar statistical software, version 5.6. Means were compared using Tukey's test, with a $5 \%$ probability level.

Correlations between the antioxidant methods and the phenolic compounds in the plant extracts from the two species were performed by means of regression analysis using the Excel software (Microsoft Corporation).

Principal component analysis (PCA) was applied to reduce the number of variables corresponding to the chemical components of the essential oils of $C$. heliotropiifolius and C. argyrophyllus. This produced a smaller number of new derived variables (principal components or factors) that adequately summarized the original information. Overall, 60 variables corresponding to the essential oil components of the two Croton species were used in PCA. This analysis was performed using the SPSS software, version 22.0 (IBM Corporation, New York, USA).

\section{Results and discussion}

\subsection{Chemical composition of the essential oils}

The essential oils composition of C. argyrophyllus and C. heliotropiifolius are described in Table 1. From the essential oil of the analyzed species, a total of 60 compounds were identified, 51 and 37 in $C$. argyrophyllus and C. heliotropiifolius respectively (Fig. 1 and Table 1). From those, 23 were exclusively identified in C. argyrophyllus and nine in C. heliotropiifolius, while 28 other compounds were present in both species. The composition of essential oils of the analyzed species differed both quantitatively and qualitatively. In a general way, the relative abundance of each identified compound differed statistically $(P<0.001)$ among species, with the exception of humulene $(P=0.713)$ and $\alpha$-muurolene $(P=0.501)$ (Table 1$)$.

The essential oil of $C$. argyrophyllus was mainly constituted by bicyclogermacrene, accounting for $14.0 \%$, followed by $\beta$-pinene $(8.9 \%)$, spathulenol $(8.7 \%)$ and caryophyllene (7.6\%) (Table 1$)$. Similarly, to the present work, the most abundant compound observed by Araújo et al. (2014) in C. argyrophyllus essential oil was bicyclogermacrene, 
Table 1

Volatile composition of the essential oils of Croton argyrophyllus Kunth and Croton heliotropiifolius Kunth (mean $\pm \mathrm{SD} ; \mathrm{n}=6$ ) (only the components with a relative area greater than $0.1 \%$ were reported).

\begin{tabular}{|c|c|c|c|c|c|}
\hline & Oil composition & LRI Lit & EOCA $(\%)^{1}$ & EOCH $(\%)^{2}$ & $P$ - value \\
\hline 1 & Tricyclene & 926 & n.d. & $0.29 \pm 0.01$ & - \\
\hline 2 & $\alpha$-thujene & 930 & $1.13 \pm 0.05$ & $1.71 \pm 0.04$ & $<0.001$ \\
\hline 3 & $\alpha$-pinene & 939 & $4.06 \pm 0.13$ & $13.30 \pm 0.17$ & $<0.001$ \\
\hline 4 & Camphene & 954 & $0.14 \pm 0.01$ & $0.91 \pm 0.02$ & $<0.001$ \\
\hline 5 & Sabinene & 975 & $1.05 \pm 0.04$ & $4.75 \pm 0.04$ & $<0.001$ \\
\hline 6 & $\beta$-pinene & 979 & $8.92 \pm 0.27$ & $1.28 \pm 0.03$ & $<0.001$ \\
\hline 7 & $\beta$-myrcene & 990 & $2.78 \pm 0.09$ & $2.52 \pm 0.04$ & $<0.001$ \\
\hline 8 & $\alpha$-phellandrene & 1002 & n.d. & $2.81 \pm 0.03$ & - \\
\hline 9 & 3-carene & 1011 & $1.61 \pm 0.08$ & n.d. & - \\
\hline 10 & $\alpha$-terpinene & 1017 & $0.12 \pm 0.03$ & $0.63 \pm 0.04$ & $<0.001$ \\
\hline 11 & $p$-cymene & 1024 & $0.33 \pm 0.02$ & $2.75 \pm 0.03$ & $<0.001$ \\
\hline 12 & Limonene & 1029 & n.d. & $16.91 \pm 0.13$ & - \\
\hline 13 & $\beta$-phellandrene & 1029 & $5.72 \pm 0.13$ & n.d. & - \\
\hline 14 & 1,8-cineole & 1033 & n.d. & $1.14 \pm 0.09$ & - \\
\hline 15 & (Z)- $\beta$-ocimene & 1037 & $0.51 \pm 0.01$ & $0.70 \pm 0.01$ & $<0.001$ \\
\hline 16 & $\gamma$-terpinene & 1059 & $0.15 \pm 0.03$ & $9.55 \pm 0.06$ & $<0.001$ \\
\hline 17 & (E)-sabinene & 1070 & $0.17 \pm 0.03$ & n.d. & - \\
\hline 18 & $\alpha$-terpinolene & 1088 & $0.40 \pm 0.03$ & $0.75 \pm 0.03$ & $<0.001$ \\
\hline 19 & Linalool & 1096 & $1.07 \pm 0.03$ & $0.36 \pm 0.03$ & $<0.001$ \\
\hline 20 & Terpinen-4-ol & 1177 & $0.17 \pm 0.01$ & $0.25 \pm 0.01$ & $<0.001$ \\
\hline 21 & Naphthalene & 1181 & $0.35 \pm 0.01$ & $0.22 \pm 0.02$ & $<0.001$ \\
\hline 22 & $\alpha$-terpineol & 1188 & $0.19 \pm 0.02$ & n.d. & - \\
\hline 23 & Bornyl acetate & 1285 & n.d. & $1.40 \pm 0.03$ & - \\
\hline 24 & $\delta$-elemene & 1338 & $0.54 \pm 0.04$ & n.d. & - \\
\hline 25 & $\beta$-terpinyl acetate & 1349 & $0.17 \pm 0.02$ & n.d. & - \\
\hline 26 & $\alpha$-copaene & 1376 & $0.13 \pm 0.01$ & $0.16 \pm 0.02$ & 0.005 \\
\hline 27 & $\beta$-bourbonene & 1388 & $0.25 \pm 0.01$ & $0.07 \pm 0.05$ & $<0.001$ \\
\hline 28 & Elemene & 1390 & $3.00 \pm 0.07$ & $0.14 \pm 0.01$ & $<0.001$ \\
\hline 29 & Gurjunene & 1409 & $0.12 \pm 0.02$ & n.d. & - \\
\hline 30 & Caryophyllene & 1419 & $7.65 \pm 0.11$ & $12.10 \pm 0.17$ & $<0.001$ \\
\hline 31 & $\beta$-gurjunene & 1433 & $0.60 \pm 0.06$ & n.d. & - \\
\hline 32 & Aromadendrene & 1441 & $0.15 \pm 0.05$ & n.d. & - \\
\hline 33 & Humulene & 1454 & $1.53 \pm 0.04$ & $1.54 \pm 0.02$ & 0.713 \\
\hline 34 & Alloaromadendrene & 1460 & $0.81 \pm 0.02$ & $0.36 \pm 0.02$ & $<0.001$ \\
\hline 35 & $\gamma$-muurolene & 1479 & $0.29 \pm 0.03$ & $0.14 \pm 0.02$ & $<0.001$ \\
\hline 36 & Germacrene D & 1485 & $0.76 \pm 0.04$ & $3.11 \pm 0.06$ & $<0.001$ \\
\hline 37 & Selinene & 1490 & $0.48 \pm 0.04$ & n.d. & - \\
\hline 38 & Viridiflorene & 1496 & $0.23 \pm 0.02$ & n.d. & - \\
\hline 39 & Bicyclogermacrene & 1500 & $14.01 \pm 0.26$ & $10.30 \pm 0.19$ & $<0.001$ \\
\hline 40 & $\alpha$-muurolene & 1500 & $0.19 \pm 0.02$ & $0.18 \pm 0.02$ & 0.501 \\
\hline 41 & Germacrene A & 1503 & n.d. & $0.12 \pm 0.06$ & - \\
\hline 42 & $\alpha$-bulnesene & 1505 & $1.92 \pm 0.02$ & n.d. & - \\
\hline 43 & $\beta$-bisabolene & 1509 & $0.24 \pm 0.02$ & n.d. & - \\
\hline 44 & $\gamma$-cadinene & 1513 & $0.52 \pm 0.03$ & $0.39 \pm 0.02$ & $<0.001$ \\
\hline 45 & $\delta$-cadinene & 1523 & $0.50 \pm 0.03$ & $0.70 \pm 0.09$ & $<0.001$ \\
\hline 46 & $\alpha$-calacorene & 1545 & $0.17 \pm 0.01$ & n.d. & - \\
\hline 47 & Elemol & 1549 & $0.73 \pm 0.03$ & n.d. & - \\
\hline 48 & $\begin{array}{l}\text { Sesquiterpene-like } \\
\text { compound } 1\end{array}$ & - & $6.23 \pm 0.14$ & n.d. & - \\
\hline 49 & Germacrene B & 1561 & n.d. & $0.18 \pm 0.04$ & - \\
\hline 50 & Spathulenol & 1578 & $8.72 \pm 0.10$ & $1.26 \pm 0.05$ & $<0.001$ \\
\hline 51 & Caryophyllene oxide & 1583 & $2.17 \pm 0.17$ & $1.52 \pm 0.13$ & $<0.001$ \\
\hline 52 & Guaiol & 1600 & $4.14 \pm 0.06$ & n.d. & - \\
\hline 53 & $\gamma$-eudesmol & 1632 & $1.51 \pm 0.03$ & n.d. & - \\
\hline 54 & $\delta$-cadinol & 1636 & n.d. & $2.11 \pm 0.04$ & - \\
\hline 55 & $\beta$-cadinol & 1653 & n.d. & $0.89 \pm 0.09$ & - \\
\hline 56 & $\begin{array}{l}\text { Sesquiterpene-like } \\
\text { compound } 2\end{array}$ & - & $1.08 \pm 0.02$ & n.d. & - \\
\hline 57 & $\begin{array}{l}\text { Sesquiterpene-like } \\
\text { compound } 3\end{array}$ & - & $1.21 \pm 0.02$ & n.d. & - \\
\hline 58 & $\begin{array}{l}\text { Sesquiterpene-like } \\
\text { compound } 4\end{array}$ & - & $1.14 \pm 0.03$ & n.d. & - \\
\hline 59 & Bunesol & 1666 & $1.13 \pm 0.04$ & n.d. & - \\
\hline \multirow[t]{2}{*}{60} & $\begin{array}{l}\text { Sesquiterpene-like } \\
\text { compound } 5\end{array}$ & - & $0.53 \pm 0.07$ & n.d. & - \\
\hline & Total identified (\%)* & & 91.71 & 97.91 & \\
\hline
\end{tabular}

LRI Lit. - linear retention index reported in literature (Adams, 2007); n. d. - not detected. ${ }^{1}$ EOCA - essential oil of $C$. argyrophyllus.

${ }^{2} \mathrm{EOCH}$ - essential oil of $C$. heliotropiifolius. that represents $27.8 \%$ of the total identified components, followed by $\delta$ elemene (8.7\%), $\beta$-elemene (8.5\%), and prenopsan-8-ol (8.5\%). However, in the work conducted by Fontenelle et al. (2008) the main compound was spathulenol (20.3\%), whereas bicyclogermacrene (11.7\%) appears in the second position. Also, spathulenol, with $14.3 \%$, was a main component in the work conducted by Morais et al. (2006), with higher values comparatively to those reported in the present study (8.7\%).

Concerning C. heliotropiifolius essential oil, limonene was the main compound, with $16.9 \%$, followed by $\alpha$-pinene (13.3\%), caryophyllene (12.1\%), bicyclogermacrene (10.3\%) and $\gamma$-terpinene (9.6\%) (Table 1). Once again, in general, other authors identified similar compounds although in different quantities. For instance, in the study conducted by Araújo et al. (2017) (E)-caryophyllene was the largest component, accounting for $23.8 \%$, followed by $\gamma$-muurolene $(10.5 \%)$ and viridiflorene $(8.1 \%)$. Whereas, in other works the main compounds were 1,8-cineole (Angélico et al., 2014) and $\beta$-caryophyllene (Neves and Camara, 2012). Still, Filho et al. (2017) characterized the essential oil of this species, in different seasons of the year, observed that the $\beta$-caryophyllene, bicyclogermacrene, germacrene-D, limonene, and 1,8-cineole were the major components, varying their relative abundance according to the season.

In general, our results are in agreement with literature for Croton species. Nevertheless, for each species, the composition of the essential oils varies. The observed differences could be attributed to a range of factors: geographical origin of plants, the characteristics of the soil and climatic conditions; season of sample collection (Gupta et al., 2011; Verma and Shukla, 2015); genetic factors and development of adaptive structures to the region; the time of collection along the day (Souza et al., 2017); and extraction conditions, among others. Other important aspect could be related to different chemotypes inside of the same species as noticed in other medicinal plants produced in the same biome. Such existence has already been proven in $C$. lichleri essential oils (Milanowski et al., 2002). Therefore, the results obtained may be indicative of new chemotypes, mainly in the case of $C$. heliotropiifolius, rich in $\alpha$-pinene (Table 1). This hypothesis need to be deeper studied in the future to verify the possible level of polymorphism within $C$. heliotropiifolius and C. argyrophyllus.

The essential oil composition was used to verify whether the two species could be grouped according to their chemical components. For this, PCA was applied to the 60 components of $C$. argyrophyllus and $C$. heliotropiifolius. The results obtained is depict in Fig. 2. The PCA showed that the two species were completely separated by the first principal component (PC1). Croton heliotropiifolius was represented in the positive region of PC1, while $C$. argyrophyllus was represented in the negative region. Three main characteristic groups of compounds (A, B, and C) could be perceived through the PCA results. Group A was composed of five compounds: $\beta$-pinene, linalool, elemene, alloaromadendrene and spathulenol (respectively numbers 6, 19, 28, 34 and, 50; Table 1). These five components were represented in the negative region of PC1, near to the samples of $C$. argyrophyllus essential oils, which means that those compounds were reported in both species, but at higher concentrations in C. argyrophyllus, thus characterizing this species. Group B was located in the opposite region and was composed by a group of seven compounds: $\alpha$-pinene, camphene, sabinene, $p$-cymene, $\gamma$-terpinene, caryophyllene and germacrene D (respectively numbers $3,4,5$, 11, 16, 30, and 36; Table 1). These seven compounds were present in both species, but with significantly higher abundance in C. heliotropiifolius, thus characterizing this species.

However, there was a third group of compounds that also characterized C. heliotropiifolius essential oils, which was represented by letter C in Fig. 2. Group C was composed of six compounds: $\alpha$-phellandrene, 1,8-cineole, bornyl acetate, germacrene A, $\delta$-cadinol, and $\beta$ cadinol (respectively numbers $8,14,23,41,54$, and 55; Table 1 ). These compounds characterized $C$. heliotropiifolius, since they were only identified in the essential oil of this species, and thus were absent from 


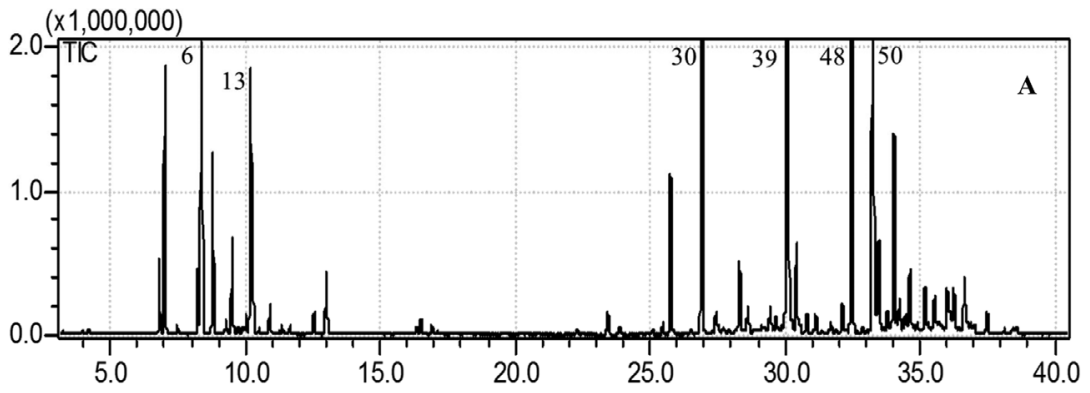

Fig. 1. Chromatographic profile of the essential oils of Croton argyrophyllus (A) and Croton heliotropiifolius (B) (numbers correspond to the compounds reported in Table 1).

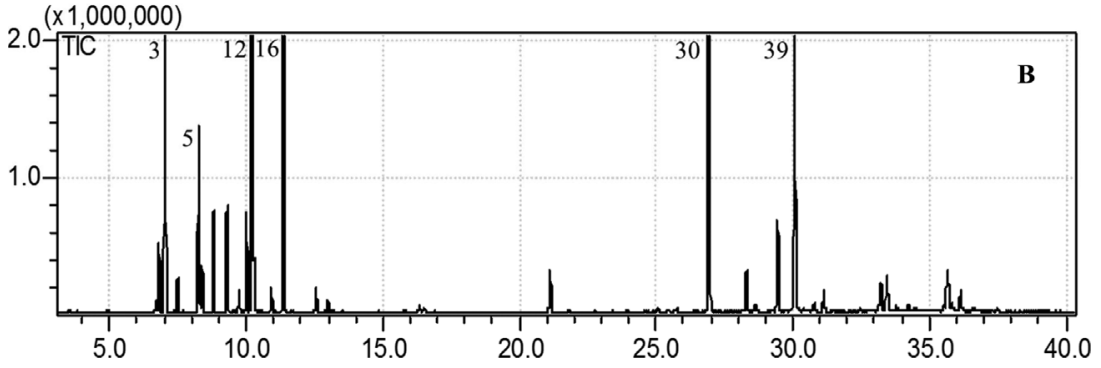

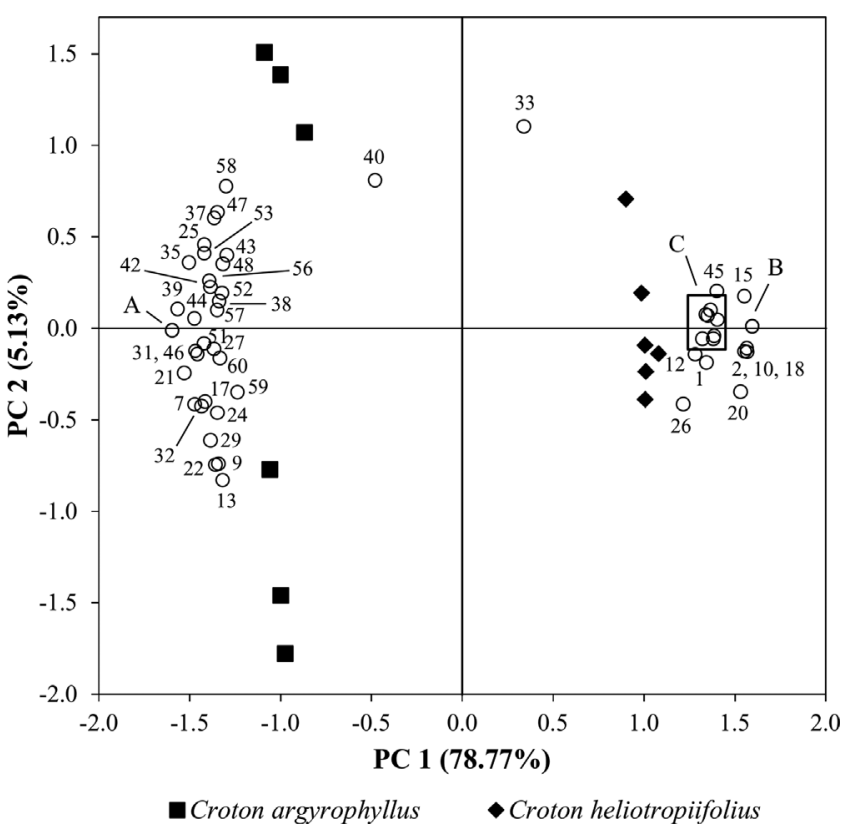

Fig. 2. Principal component analysis on the volatile composition of the essential oils of Croton argyrophyllus Kunth and Croton heliotropiifolius Kunth. The two principal components (PC) explained $83.9 \%$ of the total variance. A - compounds $6,19,28,34$ and 50 of Table 1; B - compounds 3, 4, 5, 11, 16, 30 and 36 of Table 1; C-compounds 8, 14, 23, 41, 54 and 55.

the chromatographic profile of $C$. argyrophyllus (Table 1).

In the light of the results obtained and the interpretation derived from the PCA results, these two species may have different properties and bioactive potentials. This may explain the results that are presented in the next section.

\subsection{Antioxidant activity}

The antioxidant activity of the essential oils was evaluated using the DPPH and ABTS methods. These methods assess the capacity of essential oils to scavenge free radicals and thus provide a measurement of the potential for antioxidant activity. For DPPH, the essential oils from C. heliotropiifolius possess higher antioxidant activity, with an $\mathrm{EC}_{50}$ value of $34.8 \mathrm{mg} \mathrm{mL}^{-1}$. Nevertheless, when the ABTS method was
Table 2

$\mathrm{EC}_{50}$ values for the essential oils and methanolic extracts from Croton argyrophyllus Kunth and Croton heliotropiifolius Kunth through the DPPH, ABTS and reduction power methods (mean \pm standard deviation).

\begin{tabular}{llll}
\hline Sample & $\mathrm{DPPH}^{\mathrm{a}}\left(\mathrm{EC}_{50} \mathrm{mg} \mathrm{mL}^{-1}\right)$ & $\mathrm{ABTS}^{\mathrm{a}}\left(\mathrm{EC}_{50} \mathrm{mg} \mathrm{mL}^{-1}\right)$ & $\begin{array}{l}\text { Reduction power }^{\mathrm{b}} \\
\left(\mathrm{EC}_{50} \mathrm{mg} \mathrm{mL}^{-1}\right)\end{array}$ \\
\hline $\mathrm{EOCA}^{1}$ & $46.3 \pm 2.75 \mathrm{~b}$ & $16.6 \pm 2.47 \mathrm{a}$ & - \\
$\mathrm{EOCH}^{2}$ & $34.8 \pm 3.75 \mathrm{a}$ & $22.7 \pm 6.12 \mathrm{a}$ & - \\
$\mathrm{LECA}^{3}$ & $0.222 \pm 0.008 \mathrm{a}$ & $0.245 \pm 0.037 \mathrm{a}$ & $0.658 \pm 0.021 \mathrm{a}$ \\
$\mathrm{LECH}^{4}$ & $0.357 \pm 0.004 \mathrm{~b}$ & $0.314 \pm 0.071 \mathrm{a}$ & $0.791 \pm 0.015 \mathrm{~b}$ \\
$\mathrm{SECA}^{5}$ & $1.036 \pm 0.069 \mathrm{~b}$ & $0.311 \pm 0.112 \mathrm{a}$ & $1.781 \pm 0.044 \mathrm{~b}$ \\
$\mathrm{SECH}^{6}$ & $0.782 \pm 0.040 \mathrm{a}$ & $0.398 \pm 0.011 \mathrm{a}$ & $1.281 \pm 0.065 \mathrm{a}$ \\
Trolox & $0.037 \pm 0.000$ & $0.068 \pm 0.001$ & $0.159 \pm 0.001$ \\
\hline
\end{tabular}

In each column, and for each type of extract, different letters mean statistical differences according to Tukey's test.

${ }^{\text {a }} \mathrm{EC}_{50}\left(\mathrm{mg} \mathrm{mL}^{-1}\right)$ - concentration at which $50 \%$ of the DPPH and ABTS radicals are captured.

${ }^{\mathrm{b}} \mathrm{EC}_{50}\left(\mathrm{mg} \mathrm{mL}^{-1}\right)$ - concentration at which the absorbance is 0.5 .

${ }^{1}$ EOCA - essential oil of $C$. argyrophyllus.

${ }^{2} \mathrm{OECH}-$ essential oil of $C$. heliotropiifolius.

${ }^{3}$ LECA - leaf extract of C. argyrophyllus.

${ }^{4} \mathrm{LECH}$ - leaf extract of $C$. heliotropiifolius.

${ }^{5}$ SECA - stalk extract of $C$. argyrophyllus.

${ }^{6} \mathrm{SECH}-$ stalk extract of $C$. heliotropiifolius.

tested, no significant differences were found between both species $(P=0.185), C$. argyrophyllus presented an $\mathrm{EC}_{50}$ of $16.5 \mathrm{mg} \mathrm{mL}^{-1}$ and $C$. heliotropiifolius $22.7 \mathrm{mg} \mathrm{mL}^{-1}$ (Table 2). Other works demonstrated the antioxidant activity of Croton essential oils (Ramos et al., 2013; Morais et al., 2006) with similar or better results than the obtained in this work.

For the methanolic extracts, and using the same methods, lower $\mathrm{EC}_{50}$ values ( $\mathrm{mg} \mathrm{mL}^{-1}$ ) were observed than those of the essential oils. So, a lower extract concentration was needed to neutralize $50 \%$ of the free radicals, thus generating a higher antioxidant potential. This fact could be related with the high temperatures and time used for the extraction of essential oils that could have negative impact on antioxidant molecules (Teixeira et al., 2007).

In a general way, the part of the plant used for extract preparation had a significant effect on the obtained results for the three methods used, being the leaf extracts more antioxidant than the stalk extracts $(P<0.001)$. For leaf extracts, in general, $C$. argyrophyllus is more effective and present higher antioxidant potential than $C$. heliotropiifolius with lower $\mathrm{EC}_{50}$ values $(P<0.001)$, with the exception for ABTS 
Table 3

Total phenols content (mg GAE ${ }^{-1}$ ), flavonols $\left(\mathrm{mg} \mathrm{QE}^{-1}\right.$ ) and hydroxycinnamic acid derivatives ( $\mathrm{mg} \mathrm{CAE}^{-1}$ ) in the methanolic extracts from Croton argyrophyllus Kunth and Croton heliotropiifolius Kunth (mean \pm standard deviation).

\begin{tabular}{llll}
\hline Sample & $\begin{array}{l}\text { Total Phenols } \\
\left(\mathrm{mg} \mathrm{GAE} \mathrm{g}^{-1}\right)\end{array}$ & $\begin{array}{l}\text { Hydroxycinnamic acid } \\
\text { derivatives } \\
\left(\mathrm{mg} \mathrm{CAE} \mathrm{g}^{-1}\right)\end{array}$ & Flavonols $\left(\mathrm{mg} \mathrm{QE} \mathrm{g}^{-1}\right)$ \\
\hline $\mathrm{LECA}^{1}$ & $299.47 \pm 4.89 \mathrm{a}$ & $70.29 \pm 1.71 \mathrm{a}$ & $187.93 \pm 1.41 \mathrm{a}$ \\
$\mathrm{LECH}^{2}$ & $251.52 \pm 10.50 \mathrm{~b}$ & $67.75 \pm 3.40 \mathrm{a}$ & $139.27 \pm 5.26 \mathrm{~b}$ \\
$\mathrm{SECA}^{3}$ & $242.38 \pm 4.28 \mathrm{a}$ & $51.23 \pm 1.29 \mathrm{a}$ & $125.89 \pm 2.83 \mathrm{a}$ \\
$\mathrm{SECH}^{4}$ & $201.20 \pm 18.50 \mathrm{~b}$ & $51.91 \pm 5.63 \mathrm{a}$ & $104.39 \pm 10.44 \mathrm{~b}$ \\
\hline
\end{tabular}

In each column, and for each type of extract, different letters mean statistical differences according to Tukey's test.

${ }^{1}$ LECA - leaf extract of $C$. argyrophyllus.

${ }^{2}$ LECH - leaf extract of $C$. heliotropiifolius.

${ }^{3}$ SECA - stalk extract of C. argyrophyllus.

${ }^{4} \mathrm{SECH}$ - stalk extract of $C$. heliotropiifolius.

method ( $P=0.218$ ) (Table 2). Using the DPPH method, the $\mathrm{EC}_{50}$ values for leaf methanolic extracts were $0.222 \mathrm{mg} \mathrm{mL}^{-1}$ and $0.357 \mathrm{mg} \mathrm{mL}^{-1}$ for $C$. argyrophyllus and $C$. heliotropiifolius, respectively. The values obtained with the other methodologies were higher but follow the same tendency, attesting the higher antioxidant potential for C. argyrophyllus essential oils (Table 2). For stalk methanolic extracts an opposite tendency was observed, with lower $\mathrm{EC}_{50}$ values for the extracts obtained by $C$. heliotropiifolius showing greater antioxidant potential than $C$. argyrophyllus (in DPPH and reducing power). Nevertheless, for ABTS method no significant differences were observed between the two plant species (Table 2). Previous studies have already demonstrated the antioxidant potential of stalk from Croton species (Ndhlala et al., 2013) and for the same type of extracts and using the same methodologies, the extracts of the present $\mathrm{s}$ work showed higher antioxidant potential.

The total phenols content, flavonols and hydroxycinnamic acid derivatives content of the leaf and stalk extracts from C. argyrophyllus and C. heliotropiifolius are presented in Table 3 . The species C. argyrophyllus presented higher total phenols content (299 and $242 \mathrm{mg} \mathrm{GAE} \mathrm{g}^{-1}$ ) and flavonols (188 and $126 \mathrm{mg} \mathrm{QE}^{-1}$ ) for leaves and stalks respectively in comparison to the obtained for C. heliotropiifolius (Table 3). For hydroxycinnamic acid derivatives, no significant differences were obtained for the extracts ( $P=0.312$ for leaves; $P=0.848$ for stalks) obtained from both species. The values obtained for leaf and stalk methanolic extracts from C. argyrophyllus and C. heliotropiifolius were higher than those reported in literature for other species of the genus Croton (Motta et al., 2013; Júnior et al., 2016).

The antioxidant activity of plant extracts is correlated with their chemical composition like the existence of phenolic compounds (Furlan et al., 2015). In this work, were established regression analysis between the different analyzed fractions of methanolic extracts and $\mathrm{EC}_{50}$ values for the total phenols content and different used methods. For DPPH and reducing power there was an extremely significant correlation for $C$. argyrophyllus $\left(\mathrm{R}^{2}=0.989 ; \quad P<0.001 ; y=-0.014 x+4.467\right.$ for DPPH; $\mathrm{R}^{2}=0.984 ; P<0.001 ; y=-0.019 x+6.479$ for reducing power) and very significant for $C$. heliotropiifolius $\left(\mathrm{R}^{2}=0.872\right.$; $P=0.004 ; y=-0.009 x+2.837$ for $\mathrm{DPPH} ; \mathrm{R}^{2}=0.848 ; P=0.006$; $y=-0.011 x+3.634$ for reducing power). Nevertheless, no correlation was observed for ABTS method for both species $\left(\mathrm{R}^{2}=-0.249\right.$; $P=0.965 ; y=-1.7 .10^{5} x+0.250$ for $C$. argyrophyllus; $\mathrm{R}^{2}=-0.077$; $P=0.467 ; y=-0.0004 x+0.477$ for $C$. heliotropiifolius). The results demonstrated that the composition of the extracts was preponderant for the antioxidant activity observed, and extracts with higher content of total phenols possess high antioxidant activity and low $\mathrm{EC}_{50}$, on the other side low values of total phenols are related with high $\mathrm{EC}_{50}$ values and low antioxidant activity.
Table 4

Minimum inhibitory concentrations (MIC) of essential oils and plant extracts of Croton argyrophyllus Kunth and Croton heliotropiifolius Kunth against bacteria and yeast.

\begin{tabular}{|c|c|c|c|c|c|c|}
\hline \multirow[t]{2}{*}{ Microorganisms } & \multicolumn{2}{|c|}{ Essential oil $\left(\mu \mathrm{LL}^{-1}\right)$} & \multicolumn{4}{|c|}{ Plant extract $\left(\mathrm{mg} \mathrm{mL}^{-1}\right)$} \\
\hline & EOCA $^{1}$ & $\mathrm{EOCH}^{2}$ & LECA $^{3}$ & $\mathrm{LECH}^{4}$ & SECA $^{5}$ & $\mathrm{SECH}^{6}$ \\
\hline \multicolumn{7}{|l|}{ Bacteria } \\
\hline Bacillus subtilis & 25 & - & - & - & - & - \\
\hline Bacillus cereus & 10 & - & - & - & - & - \\
\hline $\begin{array}{c}\text { Staphylococcus } \\
\text { aureus }\end{array}$ & 25 & - & - & - & - & - \\
\hline Escherichia coli & 25 & - & - & - & - & - \\
\hline $\begin{array}{l}\text { Pseudomonas } \\
\text { aeruginosa }\end{array}$ & 25 & - & - & - & - & - \\
\hline \multicolumn{7}{|l|}{ Yeast } \\
\hline Candida albicans & - & - & - & 50 & - & - \\
\hline $\begin{array}{l}\text { Candida } \\
\quad \text { parapsilosis }\end{array}$ & - & - & - & 50 & - & - \\
\hline Candida glabrata & - & - & 50 & - & - & - \\
\hline
\end{tabular}

$(-)=$ no inhibition

${ }^{1}$ EOCA - essential oil of C. argyrophyllus.

${ }^{2} \mathrm{OECH}-$ essential oil of $C$. heliotropiifolius.

${ }^{3}$ LECA - leaf extract of $C$. argyrophyllus.

${ }^{4}$ LECH - leaf extract of C. heliotropiifolius.

${ }^{5}$ SECA - stalk extract of $C$. argyrophyllus.

${ }^{6} \mathrm{SECH}-$ stalk extract of $C$. heliotropiifolius.

\subsection{Antimicrobial activity}

The essential oil of $C$. argyrophyllus inhibited all the bacterial strains tested, with MIC values ranging from $10 \mu \mathrm{LL}^{-1}$ (B. cereus) to $25 \mu \mathrm{L} \mathrm{mL}^{-1}$ (B. subtilis, S. aureus, E. coli and P. aeruginosa) (Table 4); And without any obvious difference in susceptibility between Gramnegative and Gram-positive bacteria. This oil also showed to be more potent than the antibiotic chloramphenicol $\left(30 \mu \mathrm{g} \mathrm{mL}{ }^{-1}\right)$. These findings highlight the potential use of $C$. argyrophyllus essential oil in treating infections caused by these bacteria, especially as a potential therapeutic agent for eradicating antibiotic resistance. This is of particular importance regarding $E$. coli and $P$. aeruginosa, given the increasing levels of resistance of these bacteria to multiple classes of antibiotics. Bertini et al. (2005) also used the essential oil of C. argyrophyllus to combat $S$. aureus and E. coli, and obtained MIC values of lower than $5 \%$ of oil.

The antimicrobial activity of essential oils is influenced by its chemical composition and abundance of each compound (Nazzaro et al., 2013), that could present different action mechanisms at cell level. In this work, the largest component of the oil of this species is bicyclogermacrene, a sesquiterpenoid with well-known antimicrobial activity in other essential oils (Fontenelle et al., 2008; Wijesundara et al., 2016). Other compounds present in high amounts in the EO from C. argyrophyllus were spathulenol, caryophyllene, and $\beta$-pinene. Caryophyllene is ascribed as one of the main responsible for the antifungal activity of Zingiber nimmonii against C. glabrata and C. albicans (Sabulal et al., 2006). $\beta$-pinene, as an isolated compound, was reported to inhibited the growth of some bacteria (Leite et al., 2007). The action of these compounds (either isolated or interacting with other components) may be responsible for the antimicrobial potential of Croton species including of those of the present study.

The essential oils of other species of Croton genus, also showed antimicrobial activity. The diterpenes isolated from C. nepetifolius showed action against Staphylococcus sp. strains (Sá et al., 2012); and, essential oil of $C$. rhamnifolioides inhibit the growth and survival of pathogens such as Listeria monocytogenes, Aeromonas hydrophila, E. coli and S. aureus (Costa et al., 2013). Yagi et al. (2016) using C. rotundus found MICs of $16 \mu \mathrm{g} \mathrm{mL}^{-1}$ against $S$. aureus and $32 \mu \mathrm{g} \mathrm{mL}^{-1}$ against $B$. subtilis and E. coli.

In the present work, no antibacterial nor antifungal activity was 
demonstrated by the essential oil of $C$. heliotropiifolius (Table 4). This result is in line with the obtained by Angélico et al. (2014) to the essential oil of the same species. Those author evaluate the essential oil against a variety of bacterial strains, and no positive results nor very high MICs were obtained for Staphylococcus aureus (MICs of $512 \mu \mathrm{L} \mathrm{mL}^{-1}$ ), and for B. subtilis, B. cereus, E. coli and P. aeruginosa (MICs of $1024 \mu \mathrm{LL}^{-1}$ ).

When plant extracts were tested, the antimicrobial activity was low. Nevertheless, two extracts exhibit action against important pathogenic yeasts. The leaf extract of $C$. argyrophyllus exhibited antifungal activity against $C$. parapsilosis, and the leaf extract of $C$. heliotropiifolius processes antifungal activity against $C$. albicans and $C$. glabrata, all with a MIC value of $50 \mathrm{mg} \mathrm{mL}^{-1}$ (Table 4), two-fold the result obtained with the antifungal agent fluconazole $\left(25 \mu \mathrm{g} \mathrm{mL}^{-1}\right)$. Queiroz et al. (2014) obtained best results than the observed in this work. These authors, with ethanolic extract from $C$. heliotropiifolius, found a MIC of $25 \mu \mathrm{gL}^{-1}$ against $C$. albicans.

The antimicrobial potential of plant extracts may be related to the chemical composition and the presence of some compounds like phenols (Cushnie and Lamb, 2005). Extracts obtained by Croton species, as C. macrostachyus, were rich in compounds with antimicrobial activity such as phenolic compounds, tannins and alkaloids (Teugwa et al., 2013), that could justify the antimicrobial activity of plant extracts (Jaberian et al., 2013). Nevertheless, low activity or absence of activity does not mean the absence of the compounds, once the biological potential may vary according to the solvent, the part of the plant, the quality of the material and the extraction conditions (Harvey et al., 2015).

\section{Conclusions}

The present work contributed for the characterization of the EO's and phytochemical composition of two Croton species, C. argyrophyllus and $C$. heliotropiifolius. The results indicated that both antioxidant and antimicrobial activity of $C$. argyrophyllus EO and aerial part are greater than C. heliotropiifolius. Moreover, C. argyrophyllus EO inhibited more the growth of both gram-positive and gram-negative bacteria than traditional antimicrobials tested, opening a clear window for the exploitation of these antimicrobial agents from natural sources. Nowadays this is of special importance because of the emergence of resistance to numerous conventional antibiotics. The chemical composition of the EO's allowed distinguish the two Croton species, and the results possibly point out to new chemotypes in comparison to literature. Briefly, the main conclusion of this study is that Croton species are a great source of phytochemicals with exceptional bioactive properties, and their exploitation can be helpful for different industrial sectors, mainly food sector, cosmetics, and most of all medicinal and pharmaceutical industries.

\section{Acknowledgements}

This work was financially supported by CNPQ/CsF and CAPES and UID/AGR/00690/2013 - CIMO funded by FEDER - Fundo Europeu de Desenvolvimento Regional through COMPETE2020 - Programa Operacional Competitividade e Internacionalização (POCI) - and by national funds through FCT - Fundação para a Ciência e a Tecnologia, Portugal. The authors are also grateful to UFRB Herbarium for the help with the plant species identification.

\section{References}

Adams, R.P., 2007. Identification of Essential Oil Components by Gas Chromatography/ Mass Spectrometry, fourth ed. Allured Business Media, Carol Stream.

Aguiar, F.L.L., Morais, S.M., Santos, H.S., Albuquerque, M.R.J.R., Bandeira, P.N., Brito, E.H.S., Rocha, M.F.G., Fontenelle, R.O.S., 2016. Antifungal activity and synergistic effect of acetophenones isolated from species Croton against dermatophytes and yeasts. J. Med. Plants Res. 10, 216-222.
Angélico, E.C., Rodrigues, O.G., Costa, J.G.M., Lucena, M.F.A., Neto, V.Q., Medeiros, R.S., 2014. Chemical characterization and antimicrobial activity of essential oils and Crotońs varieties modulator in the Braziliańs Northeast semiarid. Acad. J. 8, 392-397.

Araújo, S.S., Santos, M.I.S., Dias, A.S., Ferro, J.N.S., Lima, R.N., Barreto, E.O., Corrêa, C.B., Araújo, B.S., Lauton-Santos, S., Shan, A.Y.K., Alves, P.B., Santana, A.E.G., Thomazzi, S.M., Antoniolli, A.R., Estevam, C.S., 2014. Chemical composition and cytotoxicity analysis of the essential oil from leaves of Croton argyrophyllus Kunth. J. Essent. Oil Res. 26, 446-451.

Araújo, F.M., Dantas, M.C.S.M., Silva, L.S., Aona, L.Y.S., Tavares, I.F., Souza-Neta, L.C., 2017. Antibacterial activity and chemical composition of the essential oil of Croton heliotropiifolius Kunth from Amargosa, Bahia, Brazil. Ind. Crops Prod. 105, 203-206.

Berker, K., Güçlü, K., Tor, I., Apak, R., 2007. Comparative evaluation of Fe (III) reducing power-based antioxidant capacity assays in the presence of phenanthroline bathophenanthroline, tripyridyltriazine (FRAP) and ferricyanide reagents. Talanta 72, 1157-1165.

Bertini, L.M., Pereira, A.F., Oliveira, C.L.L., Menezes, E.A., Morais, S.M., Cunha, F.A., Cavalcanti, E.S.B., 2005. Perfil de sensibilidade de bactérias frente a óleos essenciais de algumas plantas do Nordeste do Brasil. Infarma 17 (3/4).

Boulanouar, B., Abdelaziz, G., Aazza, S., Gago, C., Miguel, M.G., 2013. Antioxidant activities of eight Algerian plant extracts and two essential oils. Ind. Crops Prod. 46, 85-96.

Cavin, A.L., Hay, A.E., Marston, A., Stoeckli-Evans, H., Scopelliti, R., Diallo, D., Hostettmann, K., 2006. Bioactive diterpenes from the fruits of Detarium microcarpum. J. Nat. Prod. 69, 768-773.

Compagnone, R.S., Chavez, K., Mateu, E.A., Orsini, G., Arvelo, F.O., Suarez, A.I., 2010. Composition and cytotoxic activity os essential oils from Croton matourensis and Croton micans from Venezuela. Rec. Nat. Prod. 4, 101-108.

Costa, A.C.V., Melo, G.F.A., Madruga, M.S., Costa, J.G.M., Garino Junior, F., Queiroga Neto, V., 2013. Chemical composition and antibacterial activity of essential oil of Croton rhamnifolioides leaves Pax \& Hoffm. Semina 34, 2853.

Cushnie, T.P.T., Lamb, A.J., 2005. Antimicrobial activity of flavonoids. Int. J. Antimicrob. Agents 26, 343-356.

Dória, G.A.A., Silva, W.J., Carvalho, G.A., Alves, P.B., Cavalcanti, S.C.H., 2010. A study of the larvicidal activity of two Croton species from northeastern Brazil against Aedes aegypti. Pharm. Biol. 48, 615-620.

Filho, J.M.T.A., Araújo, L.C., Oliveira, A.P., Guimarães, A.L., Pacheco, A.G.M., Silva, F.S., Cavalcanti, L.S., Lucchese, A.M., Almeida, J.R.G.S., Araújo, E.C.C., 2017. Chemical composition and antibacterial activity of essential oil from leaves of Croton heliotropiifolius in different seasons of the year. Braz. J. Pharmacogn. 27, 440-444.

Fontenelle, R.O.S., Morais, S.M., Brito, E.H.S., Brilhante, R.S.N., Cordeiro, R.A., Nascimento, N.R.F., Kerntopf, M.R., Sidrim, J.J.C., Rocha, M.F.G., 2008. Antifungal activity of essential oils of Croton species from the Brazilian Caatinga biome. J. Appl. Microbiol. 104, 1383-1390.

Furlan, C.M., Santos, K.P., Sedano-Partida, M.D., Motta, L.B., Santos, D.Y.A.C., Salatino, M.L., Negri, G., Berry, P.E., Ee, B.W.V., Salatino, A., 2015. Flavonoids and antioxidant potential of nine Argentinian species of Croton (Euphorbiaceae). Braz. J. Bot. 38, 693-702.

Grundmann, H., Kraker, M., Davey, P., 2011. Clinical impact of antimicrobial resistance: design matters. Lancet Infect. Dis. 11, 344.

Gupta, S., Bhaskar, G., Andola, C.H., 2011. Altitudinal variation in essential oil content in leaves of Zanthoxylum alatum a high value aromatic tree from Uttrakhand. Res. J. Med. Plant 5, 348-351.

Harvey, A.L., Edrada-Ebel, R., Quinn, R.J., 2015. The re-emergence of natural products for drug discovery in the genomics era. Nat. Rev. Drug Discov. 14, 111-129.

Hatano, T., Kagawa, H., Yasuhara, T., Okuda, T., 1988. Two new flavonoids and other constituents in licorice root: their relative astringency and scavenging effects. Chem. Pharm. Bull. 36, 2090-2097.

Júnior, F.B., Macedo, G.E., Zemolin, A.P., Silva, F.G., Cruz, L.C., Boligon, A.A., Menezes, I.R.A., Franco, J.L., Posser, T., 2016. Oxidant effects and toxicity of Croton campestris in Drosophila melanogaster. Pharm. Biol. 54, 3068-3077.

Jaberian, H., Piri, K., Nazari, J., 2013. Phytochemical composition and in vitro antimicrobial and antioxidant activities of some medicinal plants. Food Chem. 136, 237-244.

Leite, A.M., Lima, E.O., Souza, E.L., Diniz, M.F.F.M., Trajano, V.N., Medeiros, I.A., 2007. Inhibitory effect of $\beta$-pinene, $\alpha$-pinene and eugenol on the growth of potential infectious endocarditis causing gram-positive bacteria. Rev. Bras. Ciênc. Farm. 43, $121-126$.

Milanowski, D.J., Winter, R.E., Elvin-Lewis, M.P., Lewis, W.H., 2002. Geographic distribution of three alkaloid chemotypes of Croton lechleri. J. Nat. Prod. 65, 814-819.

Morais, S.M., Júnior, F.E.A.C., Silva, A.R.A., Neto, J.S.M., Rondina, D., Cardoso, J.H.L., 2006. Atividade antioxidante de úleos essenciais de espócies de Croton do nordeste do Brasil. Quim. Nova 29, 907-910.

Motta, L.B., Furlan, C.M., Santos, D.Y.A.C., Salatino, M.L.F., Negri, G., De Carvalho, J.E., Monteiro, P., Ruiz, A.L.T.G., Caruzo, M.B., Salatino, A., 2013. Antiproliferative activity and constituents of leaf extracts of Croton sphaerogynus Baill. (Euphorbiaceae) Ind. Crop. Prod. 50, 661-665.

Nazzaro, F., Fratianni, F., De Martino, L., Coppola, R., De Feo, V., 2013. Effect of essential oils on pathogenic bacteria. Pharmaceuticals 6, 1451-1474.

Ndhlala, A.R., Aderogba, M.A., Ncube, B., Van Staden, J., 2013. Anti-oxidative and cholinesterase inhibitory effects of leaf extracts and their isolated compounds from two closely related Croton species. Molecules 18, 1916-1932.

Neves, I.A., Camara, C.A.G., 2012. Volatile constituents of two croton species from Caatinga Biome of Pernambuco -Brazil. Rec. Nat. Prod. 6, 161-165.

Queiroz, M.M.F., Queiroz, E.F., Zeraik, M.L., Marti, G., Favre-Godal, Q., Simões-Pires, C., Marcourt, L., Carrupt, P.A., Cuendet, M., Paulo, M.Q., Bolzani, V.S., Wolfender, J.L., 2014. Antifungals and acetylcholinesterase inhibitors from the stem bark of Croton 
heliotropiifolius. Phytochem. Lett. 10, lxxxviii-xciii.

Ramos, J.M.O., Santos, C.A., Santana, D.G., Santos, D.A., Alves, P.B., Thomazzi, S.M., 2013. Chemical constituents and potential antiinflammatory activity of the essentia oil from the leaves of Croton argyrophyllus. Braz. J. Pharmacogn. 23, 644-650.

Sá, N.C., Cavalcante, T.T., Araújo, A.X., dos Santos, H.S., Albuquerque, M.R., Bandeira, P.N., da Cunha, R.M., Cavada, B.S., Teixeira, E.H., 2012. Antimicrobial and antibiofilm action of Casbane Diterpene from Croton nepetaefolius against oral bacteria. Arch. Oral Biol. 57, 550-555.

Sánchez, C.S., González, A.M.T., García-Parrilla, M.C., Granados, J.J.Q., Serrana, H.L.G., Martínez, M.C.L., 2007. Different radical scavenging tests in virgin olive oil and their relation to the total phenol content. Anal. Chim. Acta 593, 103-107.

Sabulal, B., Dan, M., John, A., Kurup, R., Pradeep, N.S., Valsamma, R.K., George, V., 2006. Caryophyllene-rich rhizome oil of Zingiber nimmonii from South India: chemical characterization and antimicrobial activity. Phytochemistry 67, 2469-2473.

Sarker, S.D., Nahar, L., Kumarasamy, Y., 2007. Microtiter plate-based antibacterial assay incorporating resazurin as an indicator of cell growth, and its application in the in vitro antibacterial screening of phytochemicals. Methods 42, 321-324.

Secco, R.S., Cordeiro, I., Senna-Vale, L., Sales, M.F., Lima, M.R., Medeiros, D., Haiad, B.S., Oliveira, A.S., Caruzo, M.B.R., Carneiro-Torres, D., Bigio, N.C., 2012. An overview of recent taxonomic studies on Euphorbiaceae s.l in Brazil. Rodriguésia 63, 227-242.

Souza, G.S., Bonilla, O.H., Lucena, E.M.P., Barbosa, Y.P., 2017. Chemical composition and yield of essential oil from three Croton species. Ciênc. Rural 47, e20161054.

Sun, J., Wang, X., Wang, P., Li, L., Qu, W., Liang, J., 2015. Antimicrobial: antioxidantand cytotoxic properties of essential oil from Dictamnus angustifolius. J. Ethnopharmacol. 159, 296-300.

Teixeira, S., Mendes, A., Alves, A., Santos, L., 2007. Simultaneous distillation-extraction of high volatile compounds from Cistus ladanifer L. Anal. Chim. Acta 584, 439-446. Teugwa, M.C., Sonfack, D.C.R., Fokom, R., Penlap, B.V., Amvam, Z.P.H., 2013. Antifungal and antioxidante activity of crude extracts of three medicinal plants from Cameroon pharmacopea. J. Med. Plants Res. 7, 1537-1542.

Verma, N., Shukla, S., 2015. Impact of various factors responsible for fluctuation in plant secondary metabolites. J. Appl. Res. Med. Aromat. Plants 2, 105-113.

Wenqiang, G., Shufen, L., Ruixiang, Y., Yanfeng, H., 2006. Comparison of composition and antifungal activity of Artemisia argyi Lévl. et Vant inflorescence essential oi extracted by hydrodistillation and supercritical carbono dioxide. Nat. Prod. Res. 20, 992-998.

Wijesundara, S.A.D.T.L., Kannangara, B.T.S.D.P., Abeywickrama, K., 2016. Antifungal Activity of Croton aromaticus L. in vitro: against post-harvest fungal pathogens isolated from tropical fruits. J. Agric. Sci. 11, 105-117.

Yagi, S., Babiker, R., Tzanova, T., Schohn, H., 2016. Chemical composition, antiproliferative, antioxidant and antibacterial activities of essential oils from aromatic plants growing in Sudan. Asia-Pac. J. Trop. Med. 9, 763-770.

van Den Dool, H., Kratz, P.D., 1963. A generalization of the retention index system including linear temperature programmed gas-liquid partition chromatography. J. Chromatogr. A 11, 463-471. 